\title{
GA による橋形構造物の組立・形態の同時最適化に関する研究*
}

\author{
菊 池 耕 生*1, 原文 雄 ${ }^{* 2}$ \\ Simultaneous Optimization of Configuration and Assembly Process \\ of Bridge Structure using a Genetic Algorithm
}

\author{
Kohki KIKUCHI and Fumio HARA
}

\begin{abstract}
In this paper, we discuss simultaneous optimization of the configuration and assembly process of a bridge structure using a genetic algorithm. The fitness function used to optimize the structure has many local minima. We propose a hybrid GA based on the "local reproduction method". We examine the performance and characteristics of the simultaneous optimization by studying three cases: (1) optimization of final structural configuration without considering assembly process, (2) optimization of the assembly process only and ( 3 ) simultaneous optimization of the final structural configuration and the assembly process. We demonstrate the effect of the assembly process on the optimum topology of the bridge structure and the applicability of this GA to multi dimensional optimization problems.
\end{abstract}

Key Words: Genetic Algorithm, Simultaneous Optimization, Structural Configuration, Assembly Process, Bridge Structure, Local Reproduction, FEM

\section{1. 緒言}

構造物の設計，プラントの配管，配線計画等では， 最小スペース問題, 最大剛性問題, 最小重量問題等, さまざまな要求が存在する。このような機械製品の複 雑化, 多様化に伴い近年ではコンピュータによる設計 の自動化が強く求められ, さまざまな論文 ${ }^{(1) \sim(3)}$ が発 表されるようになっている。これまで著者らは, 構造 物の最適化の一例として, GA を用いて静的荷重下に おける構造物の内部形態の最適化を行ってきた ${ }^{(4)}$. し かしながら, それは構造物の完成時の形態の最適化に ついてであり, 構造物によっては組立てられないこと もあり, 著者らを含め, これらを考慮したデザインは 皆無に等しい. 求めた最適形態が, コスト面, 加工面 において製造できないことも多く, 製造レベルでの諸 条件を考慮した最適化が強く求められている.

そこで本研究では, 組立工程も考慮した形態最適化 として, 橋形構造物を取上げ，その組立・形態の同時 最適化を行う。橋形構造物には, 組立工程中に構造物

\footnotetext{
* 原稿受付 1996 年 6 月 28 日。

*1 正員, 東京理科大学工学部大学院( 162 東京都新缩区神楽 坂 1-3).

*2 证員, 東京理科大学工学部.
}

として崩壊しないという構造保持の条件が加えられ, 組立工程を最適化する目的関数と構造物形態を最適化 する目的関数が互いに複雑に干涉し合うため, 非常に 多峰性の高い複雑な問題となる。このとき（1）組立。 工程を無視して最終形態の最適化のみを行った場合, (2) 許容応力内に発生応力を抑えて組立工程の最適化 を行った場合, ( 3 ) 組立工程と最終形態の同時最適化 を行った場合, の 3 ケースについて, とりうる構造形 態を比較検討する. また, このような問題に対し地域 的生殖法(後述)を用いた GA を適用して最適化を行 うことにより, GA の多次元最適化問題への有効性を 示す.

遺伝的アルゴリズム (Genetic Algorithm： GA) (5) (7) は, Hollandにより提案された生物の進化 の過程を模擬した探索アルゴリズムであり, 最適化問 題の求解法として最近注目を集めている.GA が従来 の解法に対し特徴的なことは, 多峰性の高い問題の大 域的最適解を求めるのに信頼性の高いことや, 最適化 解法が確立していなくても解の評価さえできれば比較 的短時間で実用的最適解を求められることにある. 総 当たりでは非常に時間がかかるナップサック問題や, 巡回セールスマン問題等のような問題でも, 適当な遺 伝子のコーディングによりその最適化が GA で扱え， 
突然変異, 交差, 自然淘汰等の遺伝的操作を施すこと により，実用的時間内に実用的最適解を得ることがで きる。

\section{2. モデル化とコーディング}

橋形構造物の組立・形態の同時最適化とは, 図 1 亿 示すような中心に荷重のかかる両端支持の構造物にお いて，その支持点と荷重点を含む空間に，ある設計目 的に従ってどの部材をどのようにどの順番で配置して 最終的に最適構造形態を造るかという問題である.こ れまでにも GAを用いて構造形態の最適化が行われ ているが, 図1のような両端支持の構造物の中心に組 立機械などによる荷重がかかるときの一定重量応力最 小化という設計目的から求められるものの多くは, 組 立工程の最終段階である図 $2(\mathrm{~d})$ の形態の最適化であ り，そこへ到達するまでの過程は考えられていない。 我々は, 以下に示す設計条件に従い, 構造物を図 2 (a)〜(d)のように順次組立てることにより, 構造物 の最終構造形態を決定する.

$2 \cdot 1$ 構造物のモデル 橋形構造物は, 図 2 で示 されるように組立工程において常に先端に荷重 $F$ が かかるはりとみなし, そのはりを成長させていくこと により，中心まで組立てられる，取扱いを簡単にする ために, この構造物について以下のような仮定をす る.

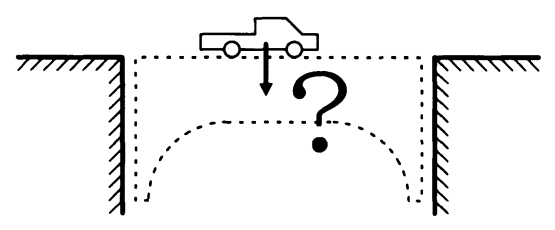

Fig. 1 Structural model

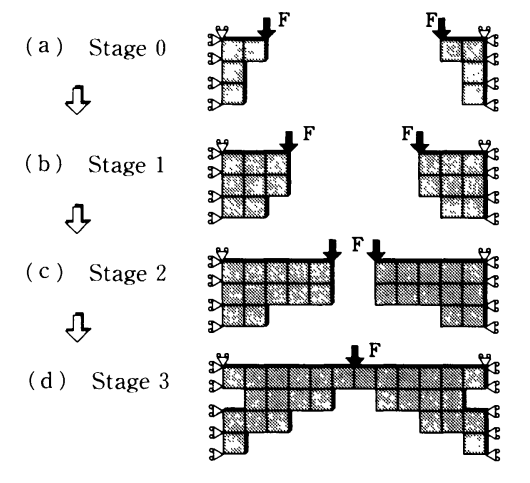

Fig. 2 Model of assembling process of structural elements
（1）構造物は二次元平面内にあるとする.

（2）構造物は壁面で支持され，各組立工程におい て常に上部最先端に $y$ 軸方向の荷重 $F$ がかかるもの とする.

（3）各組立工程(Stage)は，L個のセルで作られ るユニットを結合または取外すという作業で構成され る.

(4) 構造物は, $M \times N$ のセル空間 $(x, y)$ におい て， $(0, n)$ を壁面とし， $(1, n)$ の位置のセルが壁面で支 持され, 固定端になるものとする.

（5）セル同士は，セルの辺でのみ結合されるもの とする.

（6）各セルは, すべて同一形, 同一材料とする.

$2 \cdot 2$ 遺伝子のコーディング 染色体(個体)は, 各組立工程を表す遺伝子とジョイント数を表す遺伝子 によって表現される.図 3 の上部に各組立工程におい て付加したユニットと, その下部にそのときの構造物 形態を組立工程順に示す. 各組立工程は, $L$ 個のセル で作られるユニットで構成され，セルが空間に占める $x y$ 座標がそのまま遺伝子となる，また，セルを取除 くという遺伝子は， $x$ 座標を負にすることで表す。こ れが組立工程数 $\times L$ 個存在するため, 遺伝子は可変 長となる. ジョイント数とは, 左と右から成長し, 結 合した橋形構造物の中心 $(x=M)$ を構成するセルの総 数であると定義し, 構造物の組立終了条件に用いる. 図 3 で考えると, これは Stage 3 の $x=M$ におけるセ ルの総数であり，2である．組立工程において，中心 のセル結合数が予定されたジョイント数を満たしたと

Table 1 Expression of block assembling by chromosome

\begin{tabular}{|c|c|c|c|c|}
\hline & \multicolumn{4}{|c|}{ Genes } \\
\hline Stage 0 & $(1,5)$ & $(1,4)$ & $(1,3)$ & $(1,2)$ \\
\hline Stage 1 & $(2,3)$ & $(2,4)$ & $(2,5)$ & $(3,5)$ \\
\hline Stage 2 & $(3,4)$ & $(4,4)$ & $(4,5)$ & $(5,5)$ \\
\hline Stage 3 & $(5,4)$ & $(6,5)$ & $(6,4)$ & $(6,5)$ \\
\hline Joint Number & \multicolumn{5}{|c|}{2} \\
\hline
\end{tabular}

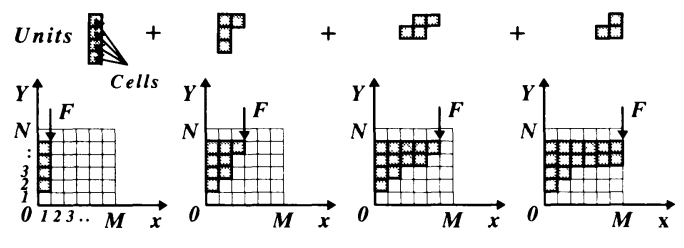
Stage 0 Stage 1 Stage 2 Stage 3

Fig. 3 Assembling model 
きに, 構造物は完成形(最終形態)をむかえる. 本来こ の遺伝子は, 構造形態には関与しないものであり, そ れなしでも構造物を構成することはできるが, 未完成 構造や組立過多といった主に初期世代における致死遺 伝子を避け, 個体群の収束性を向上させるために取入 れた。

以上のようにコーディングすることにより，図 3 の ような組立工程を有する橋形構造物の遺伝子は, 表 1 のように表せる.

\section{3. 設計における評価}

$3 \cdot 1$ 評価関数 各個体の適応度の評価に以下の 式を用いる。ここで, 総合評価関数式 (1)には, 組立 工程を最適化する関数 $f_{1}$ と最終形態を最適化する関 数 $f_{2} \sim f_{4}$ が含まれ, 非常に複雑な問題となる. 例え ば, 構造物全体の応力を表す $f_{2}$ と構造物の重量を表 す $f_{3}$ 等は互いに反対の方向性を持つなど，すべての 構成関数の最小化は不可能である. そこで本研究で は, 設計者の目的にあわせた各構成関数の重み係数 $\alpha_{k}$ を用いて，そのときの総合評価関数 $F$ の最小值を 求める.

$$
\begin{aligned}
F & =\frac{\sum_{k=1}^{4} \alpha_{k} f_{k}}{\sum_{k=1}^{4} \alpha_{k}} \ldots \ldots \\
f_{1} & =\sum_{k=0}^{\text {Stage }} \sigma_{\max (k)} \cdots \\
f_{2} & =\sigma_{\max }(\text { Stage }) \\
f_{3} & =\text { Total(Stage) } \\
f_{4} & =\text { Flat }(\text { Stage })
\end{aligned}
$$

$f_{1}$ : 各ステージにおける最大応力 $\sigma_{\max }$ の累積值.

$f_{2}$ : 最終形態における最大応力 $\sigma$.

$f_{3}:$ 構造物全体を構成するセルの総数.

$f_{4}:$ 上端の平坦さ.

Stage : 組立工程数.

$\alpha_{k}:$ 重み係数

ここで, $f_{1}, f_{2}$ の值は, 有限要素法(FEM) ${ }^{(8)}$ により 求める。このとき, Misesの降伏条件を越えたものに ついては, 崩壊を意味させ, 適応度を下げる目的でそ れらの值を 100 倍する. 組立工程の最適化を意味する $f_{1}$ の值には, 組立工程中における構造物が崩壊しない という構造保持の要求と組立工程数の最小化のため, 各組立工程における最大応力値の累積値を採用した。 また，最終形態の最適化を意味する $f_{2}$ は橋形構造物 の強度を, $f_{3}$ は構造物の材料費や重量を, そして $f_{4}$ は 橋形構造物上部の平坦さをそれぞれ表す。

以上, 上記のモデルにおいて, 総合評価関数 $F$ の値

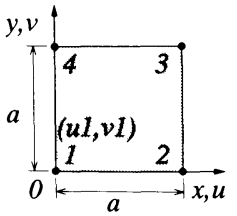

Fig. 4 2-dimensional FEM element

を最小にするようなユニットの組立と橋形構造物の形 態を求める。

$3 \cdot 2$ FEM による計算法 本研究では, 二次元構 造物の一つのセルを正方形のセルでモデル化したた め, 有限要素は一辺が $a$ の二次元四角形要素とした。

まず, $M \times N(=12 \times 20)$ のフィールドにおける任意 の位置 $(m, n)$ の七ルについて考える. 図 4 に示すよ うに，セルの節点に反時計回りに $1,2,3,4$ と番号をつ け, 各節点の変位を $\left(u_{i}, v_{i}\right)(i=1,2,3,4)$ と置くと, セ ル内の任意の点 $(x, y)$ における変位は,

$$
u=\sum_{i=1}^{4} u_{i} N_{i}(x, y), \nu=\sum_{i=1}^{4} \nu_{i} N_{i}(x, y)
$$

と表せる。ここで $N_{i}$ は

$$
\left.\begin{array}{l}
N_{1}=\frac{(x-a)(y-a)}{a^{2}}, N_{2}=\frac{-x(y-a)}{a^{2}} \\
N_{3}=\frac{x y}{a^{2}}, N_{3}=\frac{-(x-a) y}{a^{2}}
\end{array}\right\}
$$

で示される内挿関数であり, 材料を等方性であると仮 定すると, 応力ーひずみ関係式は,

$$
\sigma=\frac{E}{(1+\nu)(1-2 \nu)}\left[\begin{array}{ccc}
1-\nu & \nu & 0 \\
\nu & 1-\nu & 0 \\
0 & 0 & (1-2 \nu) / 2
\end{array}\right]
$$

$\nu:$ Poisson Ratio

$E$ : Young Modulus

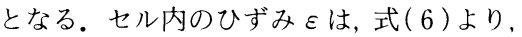

$\varepsilon=A u$

$A=\left[\begin{array}{cc}\partial / \partial x & 0 \\ 0 & \partial / \partial y \\ \partial / \partial y & \partial / \partial x\end{array}\right]$

となる.ここで,

$$
\begin{aligned}
& u^{*}=\left[u_{1}, \nu_{1}, u_{2}, \nu_{2}, \cdots, u_{4}, \nu_{4}\right]^{T} \\
& N=\left[\begin{array}{lllllll}
N_{1} & 0 & N_{2} & 0 & \cdots & N_{4} & 0 \\
0 & N_{1} & 0 & N_{2} & \cdots & 0 & N_{4}
\end{array}\right]
\end{aligned}
$$

となるような変位ベクトル $u^{*}$ と, マトリックス $N$ を 導入すると,ひずみ $\varepsilon$ は,

$$
\varepsilon=A N u^{*} \equiv B u^{*}
$$

と表せる。また，任意の位置の要素の要素剛性マトリ 
ックス $k$ は

$$
k=\int_{V} B^{T} D B d V
$$

であり，各節点にかかる体積力と各節点における変位 u*の関係は、

$$
f^{*}=k u^{*}
$$

となる。これをその丁程での構造全体に拡張すれば, 以下の式を得る。

$$
F^{*}=K U^{*}
$$

ここで， $F^{*}$ は，図 3 で示される外力べクトルであり， $U^{*}$ は, すべての有限要素の節点の変位べクトルであ る， $K$ は，要素剛性マトリックス $k$ で合成される全 体剛性マトリックスである。

以に:により, 式( 8 )から, 任意の要素 $(m, n)$ におけ る節点の忘力 $\sigma$ が求められる。この計算をフィール ド内すべての要素について行い, 最大忍力 $\sigma_{\max }$ を求 める。この $\sigma_{\max }$ を, 各組立程に拀いて累積したも のを $f_{1}\left[\right.$ 式(2)] とし, 最終形態においては $f_{2}[$ 式 (3)] とする.

$3 \cdot 3$ 初期集団の生成まずはじめに、ジョイン ト数をランダムに決定寸る. 次に、フィールド内の任 意の点 $(x, y)$ にルを生成する。このとき，このセル が固定端もしくは他のセルと結合できなかった場合 は，睬 50 の（a）で示されるように，セルを $x$ 軸の傎の 方向にシフトし，浮遊しないようにする。また，すで にその座標にセルが存在する場合はセルを $x$ 軸の正 方向にシフトし，セルの重複を避ける。次に，図５の (b)で示されるように，その前後左存 4 セル内に次の セルを生成する。このセルについても上記と同様の補 让を行う。これを $L$ 叫繰返して 1 ステージ $L$ 個のセ ルを生成し，阙５0（c）で示されるようなユニットと する。この作業をステージ単位でジョイント数を満た すまで繰返すことにより，初期個体とする。

以上を湖体数だけ繰返し，初期集囦を発生させる。

$3 \bullet 4$ 淘汰と増殖本研究では, 式(1)で示され るように, 総合詊価関数内のそれぞれの構成関数が 複雑に渉しあい，非常に多峰性の高い解空間をもつ ていると考えられる。このような場合，個体群は初期

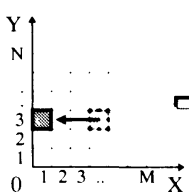

(a) 0 Step

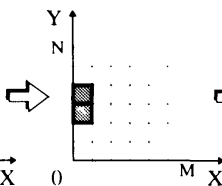

(b) 1 step

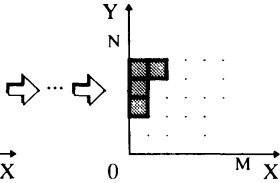

(c) I. Step
Fig. 5 Process of structural connection development
收束しやすく，ある局所解に陥りやすい，そこで我々 は, 探索可能な空間を広げ, 初期収束を避けて各構成 関数 $f_{1} \sim f_{4}$ の影響を反映した地域的な遺伝子を残し 空間探索度を上げるために,より地域的な生殖法 (Local Reproduction Method) を提案する.図 6 の ように互いに逆向きに干渉しあう関数 $f_{a}(x)$ と $f_{b}(x)$ によって構成される総合評価関数 $H\left(f_{a}(x), f_{b}(x)\right)$ の 最小值 (または最大値)を求める場合, 一般的淘汰に より生殖を行えば, 初期集団では総合評価值のよい確 率の高い図 6 の $C$ 領域の遺伝子が選択されやすく, 極小值の空間の狭い図 6 の $A$ や $B$ の領域に存在する 遺伝子はとうたされやすい。このため, 図 6 の $C$ の 領域に初期収束しやすく, 最適解の探索率は低くな る.よってこのような場合には, 構成関数 $f_{a}(x)$, $f_{b}(x)$ を反映した遺伝子による総合評価関数 $H$ への アプローチが必要となる。次に,この具体的手法を示 寸.

図 7 に, 地域的な生殖法による次世代の集団の生成 図を示す。まず始めに, トーナメント方式により評価 值のよい順に全体の $10 \%$ を選択する [図 7 (A)]. 続 いて $40 \%$ を総合評価関数 $F$ を用いた普通のルーレッ トルールで選択し [図 7 (B)]，残り $50 \%$ を以下に述 ベるローカルなルーレットルールで選択する［図 7 (C) ]. まず, 総合評価関数 $F$ 内のそれぞれの構成関 数 $f_{k}$ を重視した $F^{\prime}{ }_{(k, n)}$ によるルーレット板を各構成

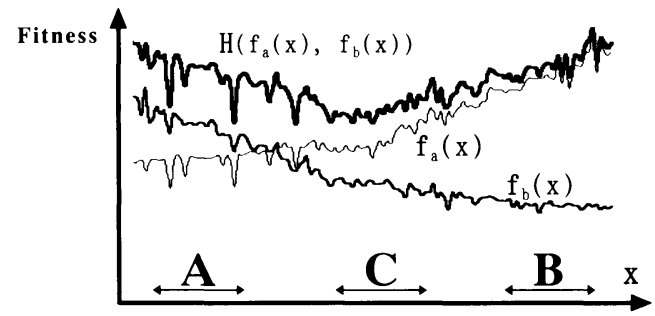

Fig. 6 Picked region by Local Reproduction

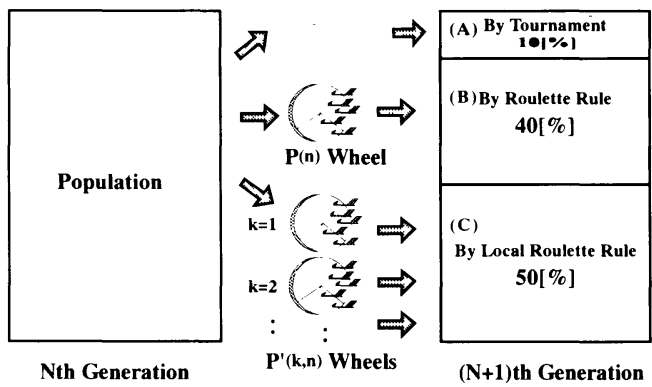

Fig. 7 Group of next generation by Local Reproduction 
関数ごとに用意する $[$ 式 $(19)]$. ここで， $F_{(k, n)}^{\prime}$ の板 を用いたルーレットで個体 $n$ が選択される確率 $P_{(k, n)}$ は, 式(18)のようになる。

$$
\begin{aligned}
& P_{(k, n)}=\frac{F_{(k, n)}^{\prime-2}}{\sum_{p=1}^{P O P} \frac{F_{(k, p)}^{\prime-2}}{P O P}} \\
& F_{(k, n)}^{\prime}=e_{(g)}\left(\sum_{l=1}^{4} \alpha_{l} f_{l}-\alpha_{k} f_{k}\right)+\alpha_{k} f_{k} \\
& e_{(g)}=\frac{1}{1+\exp \left\{-20\left(\frac{g}{G}-0.25\right)\right\}}
\end{aligned}
$$

$e(g)$ : 各評価値における重み関数

$$
\begin{aligned}
& g: \text { 世代数 } \\
& n: \text { 個体番号 } \\
& G: \text { 全世代数 } \\
& m: \text { 各評価値番号 }
\end{aligned}
$$$$
P O P \text { : 個体数 }
$$

式(20)はNeural Networkなどで用いられるシグモ イド関数であり，世代が進むにつれて $0.0 \sim 1.0$ まで 変化し, 図 8 のようになる。これにより, 構成関数 $f_{k}$ を重視した評価值 $F^{\prime}(k, n)$ は, 初期世代では $f_{k}$ の影響 を強く受け $f_{k}$ の值のよいものを次世代の個体として 選択するようになる。 また, 世代が進むにつれて総合 評価的効果が強くなり, 最終世代では一般的なルーレ ットルールを用いた生殖と同様となる。このような地 域的な生殖法と普通の生殖法を 100 回のシミュレーシ ヨンにおいて比較実験した結果, 平均的に約 $10 \%$ の適 応度の向上が見られた。このことは,この方法が普通 の生殖法に対し, 局所解に陥ることが少なく, 最適解 により収束しやすいことを意味しており, 評価関数に おける構成関数がトレードオフの関係にあって局所解 に初期収束しやすい問題に対しては, 効果のある方法 であるといえる。

$3 \cdot 5$ 交差交差には, Cut \& Splice, 最終形一直 線交差の二つを用い, それぞれをランダムに選択する

\section{ようにした。}

Cut \& Splice は, 図 9 に示すような遺伝子形で行う 交差で, 常にステージ単位で行うものとする。この交 差では遺伝子の長さが変化するため, セルが構造物の

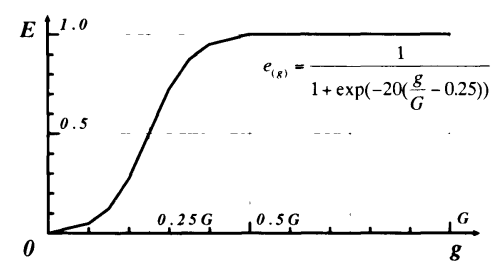

Fig. 8 Sigmoid function
中心まで届かず，致死遺伝子となるものが現れる．こ のようなものについては, 後述する “致死遺伝子”の 項に示す方法で復活させるものとする.

また，本研究においては，Cut＆ Spliceだけでは， 巡回セールスマン問題における交差の問題(一方の)親 の特徵しか継承しにくいという問題)と同じような問 題が発生し進化しにくいため, 最終形状で交差しその 後に組立てを決定するという最終形一点交差をも取入 れた。これはまず選択された親 $A$ と親 $B$ を図 10 で示すように，ランダムな直線をもつて二次元的に交 差させ, その後, ユニットの整合性をとりながら組立。 てていくという表現形を用いた交差である.

交差確率 $C(t)$ には, 個体群の収束率の変化に伴い 確率が変化する以下の式を用いた。

$$
C_{(t)}=0.3\left(0.5+0.5 \frac{F_{\min }}{F_{\text {ave }}}\right)
$$

$F_{\min }$ ：その世代における最小評価値

$F_{\text {ave }}$ ：その世代における半均評価值

これは，多様性のある初期世代においては，スキーマ を破壊するだけのむだな交差は避け，世代が進み局所 探索に入ったときに交差数を増やして山登りの速度を 上げるという効果を期待している，以上により，交差 確率 $C(t)$ は, 世代数 $t$ の増加や個体群の収束率の変 化により，一般的に $0.2 \sim 0.3$ の間を変化する.

$3 \cdot 6$ 突然变異 突然変異率 $M(t)$ には, 世代数 と個体群の収束率の変化に伴い確率が変化する以トの 式を用いた。

$$
M_{(t)}=0.03\left\{0.5+5.0\left(\frac{g}{G}\right)^{6}\right\} \frac{F_{\min }}{F_{\text {are }}}
$$

これにより突然変異率 $M(t)$ は, 如代数 $t$ の増加と,

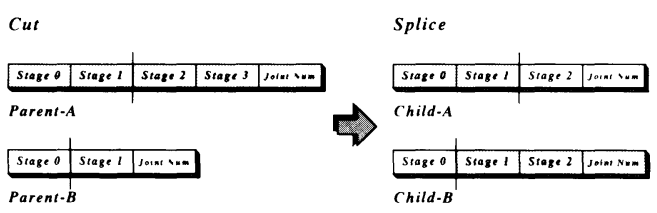

Fig. 9 Procedure of Cut \& Splice crossover

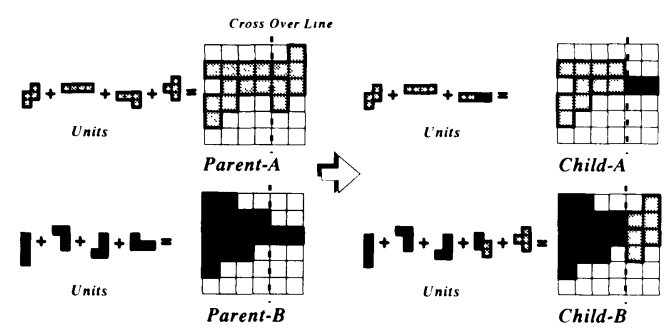

Fig. 10 Procedure of final-structure crossover 
個体群の収束状況に伴い,一般的に図 11 のように変 化する.ここで, 突然変異が確定した個体は, 互いに 独立に（A) 100\%，(B) 50\%，（C）50\%の確率で，それ ぞれ以下の 3 種の突然変異パターンを選択する.

(A) Mutation-A：ランダムな位置のセルをその近 傍 8 セル内に移動させる突然変暴.

（B） Mutation-B：ランダムに選んだ二つのステー ジ内の遺伝子をすべて交換 (ユニットを交換)する突然 変異.

(C) Mutation-C：図 12(a)の点線で示されるよう な, 二次元フィールドで組立てられた構造物のランダ ムなある範囲に対し, 遺伝子の $y$ 軸値に土1でゆらぎ をかけ, 図 $12(\mathrm{~b})$ のようにセルをスライドさせる突然 変異.これは, 徐々に形態を整えていくことにより, アニーリングに似た効果をもつ.

以上により, 解に多様性のある初期世代では突然変 異率を低めにして無駄に探索空間を広げることを防 ぎ, その後徐々に上げていくことにより効率のよい探 索空間の調整を行う。また, 後期世代においては, $\mathrm{GA}$ が探索している局所解近傍での突然変異個体 (Mutation-A Putation-Cのような, ビルディン グブロックのある程度確立した後期世代においては, 現在探索している山を離れることのないような微小な 変異をもつ突然変異個体)を増やすことにより, 局所 解への山登りを高速化する効果を得る.

$3 \cdot 7$ 致死遺伝子の防止 交差や突然変異の過程 において, セル同士が辺で結合されない浮遊構造をも つ遺伝子や, 同一領域内にセルがいくつも重なってし まう遺伝子が生成される場合がある.このような構造 物として成立しない遺伝子(致死遺伝子) を次のよう に変更する.浮遊構造については図 5 ( a )で示したよ うな $x$ 軸の負の方向にシフトさせ, 重複構造について

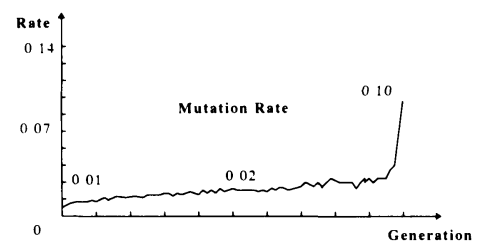

Fig. 11 Mutation rate in terms of generation

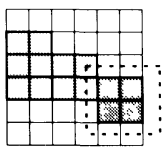

(a) Before Mutation - $\mathrm{C}$

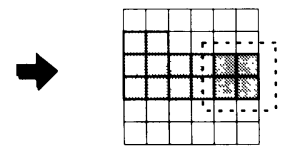

(b) After Mutation-C
Fig. 12 Explanation of mutation $\mathrm{C}$
は $x$ 軸の正の方向にシフトさせる.ここで, $x$ 方向の シフトによりフィールドの範囲を超えてしまうもの は, セルの重複を許すこととする.この場合，1 ステ ージが $L$ 個以下のセルで構成される遺伝子が生成さ れる. また, ジョイント数条件を満たさない遺伝子に ついては, ステージ数を増やして新たにユニットを加 えるという作業を条件を満たすまで繰返す。これによ り, 遺伝子はより広い解空間を探索することになり, 収束性の向上が期待される. 以上, 交差や突然変異に よって選択されたすべての遺伝子に対しこれらの作業 を行った.

\section{4. シミュレーション}

式（1）に用いる各係数 $\alpha_{1} \sim \alpha_{4}$ の值を表 2 に示す. シミュレーションには, Pattern 1：最終形状におけ る応力を重視し係数 $\alpha_{2}$ の值を大きくしたもの, Pattern 2 : 組立工程中の応力を重視し係数 $\alpha_{1}$ の值を大 きくしたもの, Pattern 3: 組立と最終形状の両面に おける応力を考虑したもの，の 3 パターンを用いた。

以上を基に, 個体数 $P O P=200$, 世代数 $G=300$ と して各 100 回シミュレーションを行う.ここで個体数 と世代数は, 探索空間の範囲や世代による進化率等を 考慮して予備実験した結果上記のように決定した.

Table 2 Weighting parameter values

\begin{tabular}{|c|c|c|c|c|}
\hline Fitness Weight & $\alpha_{1}$ & $\alpha_{2}$ & $\alpha_{3}$ & $\alpha_{4}$ \\
\hline Pattern 1 & 0.0 & 5.0 & 1.0 & 2.0 \\
\hline Pattern 2 & 0.2 & 0.0 & 1.0 & 2.0 \\
\hline Pattern 3 & 0.2 & 5.0 & 1.0 & 2.0 \\
\hline
\end{tabular}

Table 3 Minimum fitness values for Pattern 1, 2 and 3 (100 trials)

\begin{tabular}{|c|c|c|c|}
\hline & \multicolumn{3}{|c|}{ Fitness } \\
\cline { 2 - 4 } & Average & Best & Worst \\
\hline Pattern 1 & 10.4 & 9.50 & 11.0 \\
\hline Pattern 2 & 8.98 & 7.12 & 11.5 \\
\hline Pattern 3 & 13.1 & 12.7 & 13.4 \\
\hline
\end{tabular}

Table 4 Component fitness values for Pattern 1,2 and 3 (100 trials)

\begin{tabular}{|c|c|c|c|c|}
\hline & \multicolumn{4}{|c|}{ Local Fitness } \\
\cline { 2 - 5 } & $f 1$ & $f 2$ & $f 3$ & $f 4$ \\
\hline Pattern 1 & $(17400)$ & 15.3 & 34 & 0 \\
\hline Pattern 2 & 91.2 & $(32.9)$ & 30 & 0 \\
\hline Pattern 3 & 128 & 13.8 & 47 & 2 \\
\hline
\end{tabular}


5. 結 果

Pattern 1，2 および 3 における 100 回のシミュレー ション結果を左側からそれぞれ平均, 最も評価值のよ い解，最も評価值の悪い解として表 3 に示す。次に， 各パターンにおける各構成関数值 $f_{1} \sim f_{2}$ を表 4 に示 す.ここで, 括弧内の数字は係数が零のため評価関数 に関与していないことを表す。また，各パターンにお ける GA による最適解と, 全体の左側 $1 / 2$ の領域にお

ける主応力線図をそれぞれ図 13〜15 に示す.

組立・形態の同時最適化という非常に解空間の広い 問題にもかかわらず，表 3 の評価值において 100 回の 試行に対する分散值は小さく, GA で求めた解の信頼 性は高いといえる。

Pattern 1 は, 組立工程を考慮しない従来型である ため, 最小重量平均応力という概念から, 構造物内に
空間を有する三角形トラス構造となっている。この構 造は, 材料力学的構造物の形態最適化という面では, ほほ最適解と呼ぶことができるであろう。しかし，こ こで組立工程中について考えると, この構造物は, 図 13 の Stage 1 に見られるように曲げ剛性の小さい片

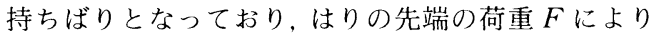
非常に大きな応力が発生している. よって, 生産性, 安全性の視点から見れば, 最適解であると呼ぶことは 難しい.

Pattern 2 は, 組立工程の最適化であるので, 許容 範囲内応力においての組立工程数の最小化を行ってい る.また, 組立工程中において最も応力が大きくなる のは構造物が両端支持される直前の片持ちばりの状態 のときであり，この状態におけるはりの長さを短くす ることが組立工程の最適化につながる、本シミュレー ションでは, 8 Cells/Stage としたために図 14 に示さ

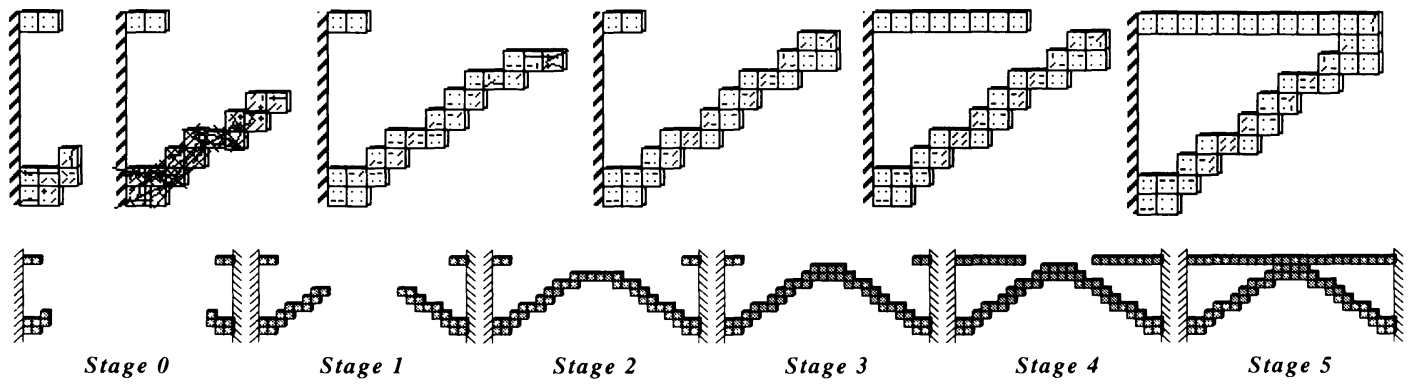

Fig. 13 Optimal topology and assembling process obtained by GA (down) and principal stress distribution for the test Pattern 1 (up)
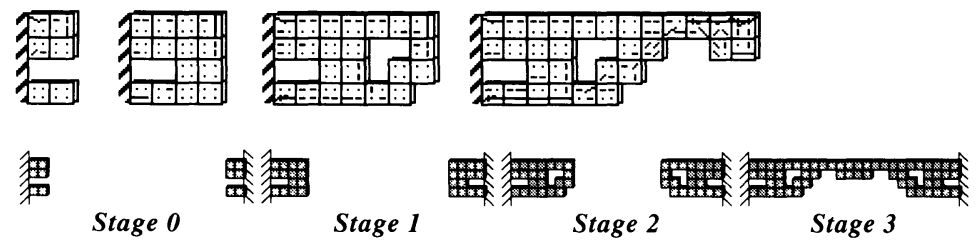

Fig. 14 Optimal topology and assembling process obtained by GA (down) and principal stress distribution for the test Pattern 2 (up)

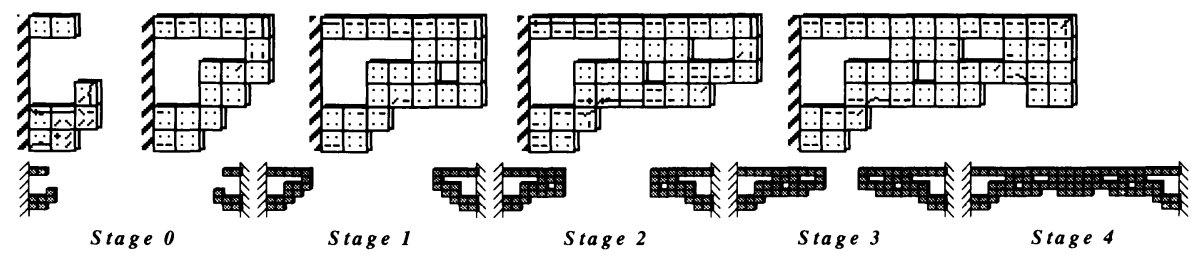

Fig. 15 Optimal topology and assembling process obtained by GA (down) and principal stress distribution for the test Pattern 3 (up) 


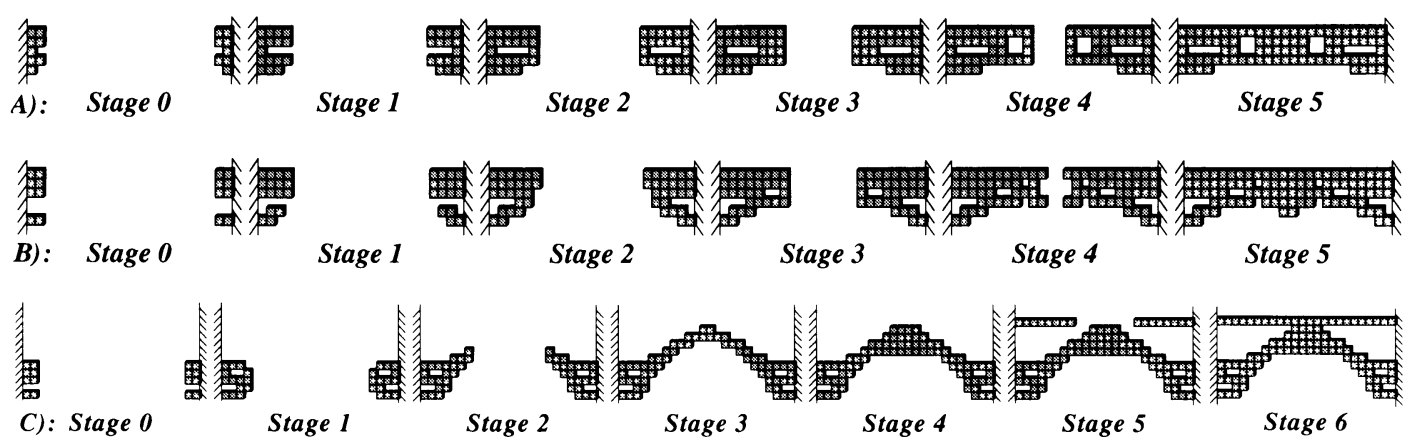

Fig. 16 Examples of topology and assembling process obtained by GA for the test Pattern 3 $[\mathrm{A}]: \mathrm{F}=13.3, \mathrm{~B}): \mathrm{F}=13.3, \mathrm{C}): \mathrm{F}=13.4]$

れるような形状が多く見られたが，1 ステージにおけ るセル数を変えることによりほかにもさまざまな組立 工程が見られると思われる。例えば, 8 Cells/Stage の条件のために生成不可能であった図 13 のような組 立.程を考慮しない最適解も，16 Cells/Stageにする ことにより生成可能になる。

組立工程と形態の両面からの最適化である Pattern 3 では, 図 $15 に$ に示すうに, 最終形状においては最小 重量で応力最小化を行い, 組立工程中のどの段階にお いても許容範四内の発生応力で組立工程数の最小化を 行っている. 最終形態における最大応力値を比較する と, Pattern 3 の $f_{2}=13.8$ という值は, Pattern 1 の $f_{2}$ $=15.3$ とほとんど変わらず, 形態最適化という概念に おいて目的は達成されているといえる. また, 組立工 程中の累積最大応力值 $f_{3}$ を比較しても, Pattern 3 の $f_{3}=128$ という值は, Pattern 2 の $f_{3}=91.2$ に対し大差 はない. 以上から, 組立工程と形態の同時最適化が成 功したということができる.

また, 最後に Pattern 3 における特徵的な解の例を 図 16 に紹介する。ほとんどの解が, 図 $16 \mathrm{~A}$ ), B)の ように片持ちばりのような形状を徐々に成長させて結 合するという組立工程を有する. また, 図 16 C)のよ うに最小組立工程数で左右を結合し, 安定形態として から最終的に形態を整えていくという解も存在する. こ0方法を用いると極めて Pattern 1 に近い解が得ら れるが、組立匡程数が増えるという久点があり全体の 評価はあまりよくない。

\section{6. 結言}

本研究では，橋形構造物の組立最適化と形態最適化 という互いに干涉し合う目的関数の最小化問題を GA を用いて解く才j法を検討し，その具体的設計法を構築 した。これにより，以下のことが明らかになった。
（1）目的関数に組立工程を含めることにより, 組 立工程の全段階で構造的に安定でしかも最適組立工程 のうちに組立つ最適構造形態を求めることができた.

（2）本問題のように, 構造物を構成する要素の組 合せが膨大な解空間においても, 地域的生殖法を用い た GA を適用して求めることにより精度よく最適構 造形態を得ることができた。

（3）上述のような組立行程・形態の同時最適化問 題のように, 目的関数が複雑な多次元最適化問題に対 する GA の有効性を示した。

本研究における同時最適化は, 現実問題を抽象して, その最適化の特性がよりよく見られるように, 評価関 数における構成関数を四つに限って行った. より現実 問題へのアプローチとしては, 評価関数に現場の二ー ズに応えるような関数を新たに組込むことが考えられ る.

\section{文献}

（1）古口日出男・渡辺浩・矢田敏夫, 遺伝的アルゴリズムを 用いた二次元弾性逆解析, 機論, 60-572, A (1994)，10291034 .

（2）坂本二郎・尾田十八，遺伝的アルゴリズムを利用した最 適トラス形態决定法, 機論, 59-562, A (1993)，1568-1573.

（3）朝山正輝・長谷川浩志・川面恵司, GA を利用した応力制 約下におけるトラス構造の寸法最適化に関する一数値実 験, 機論, 62-597, A (1994), 1234-1241.

(4) Hara, F. and Kikuchi, K., Topology Optimization by Genetic Algorithm for Smart Structure Element, Fifth Int. Conf. Adaptive Structures, (1994), 439-449.

（5）安居院猛・長尾智晴、ジェネティクアルゴリズム、 (1993). 昭晃堂.

（6）北野宏明, 遺伝的アルゴリズム(1993), 産業図書.

( 7 ) Holland, J. H., Adaptation in Natural and Artificial System. Ann Arbor, (1972), MI: University of Michigan.

(8) Tong, P. and Rosettons, J. N., エンジニアのための有限 要素法. (1983), 共立出版. 